\title{
KNOWLEDGE SHARING MANAGEMENT: STRATEGY FOR IMPROVING THE QUALITY OF HUMAN RESOURCES
}

\author{
Hasan Baharun ${ }^{1}$, Hefniy $^{2}$, Silviani $^{3}$, Muhammad Anas Maarif ${ }^{4}$, Adi Wibowo ${ }^{5}$, \\ ${ }^{123}$ Islamic Educational Management Department, Universitas Nurul Jadid, \\ Probolinggo, East Java, Indonesia \\ ${ }^{4}$ Islamic Educational Management Department, Institut Pesantren KH Abdul Chalim, \\ Mojokerto, East Java, Indonesia \\ ${ }^{5}$ Islamic Educational Management Department, Sekolah Tinggi Agama Islam An-Nawawi, \\ Purworejo, Central Java, Indonesia \\ Email: ha54nbaharun@gmail.com ${ }^{1}$, hefniy@gmail.com², zilviajiminssi2323@gmail.com ${ }^{3}$ \\ anasdr16@gmail.com ${ }^{4}$, adiwibowo@yahoo.com ${ }^{5}$
}

DOI: http://doi.org/10.33650/al-tanzim.v5i1.1831

\begin{tabular}{l|l|l} 
Received: January 2020 & Accepted: March 2021 & Published: March 2021
\end{tabular}

\begin{abstract}
:
This study aims to analyze and understand about analyzing the knowledge sharing strategy carried out by SMA Nurul Jadid, Paiton, Probolinggo in improving the quality of its human resources. This research uses a qualitative approach to the type of case study. Data collection techniques are carried out through interviews, observation, and documentation. Data analysis was carried out through display data, data reduction and conclusion drawing. The results showed that the strategy to improve the quality of human resources through knowledge sharing at SMA Nurul Jadid was carried out through; utilize materials, talk space, knowledge sharing culture, benchmarking best practices.
\end{abstract}

Keywords: Knowledge sharing, Human Resources, Quality

\begin{abstract}
Abstrak:
Penelitian ini bertujuan untuk menganalisis dan memahami tentang strategi knowledge sharing yang dilakukan oleh SMA Nurul Jadid, Paiton, Probolinggo dalam meningkatkan kualitas sumber daya manusianya. Penelitian ini menggunakan pendekatan kualitatif jenis studi kasus. Teknik pengumpulan datanya dilakukan melalui interview,observasi, dan dokumentasi. Analisis datanya dilakukan melalui data display, data reduction dan penarikan kesimpulan. Hasil penelitian menunjukkan bahwa strategi peningkatan kualitas sumber daya manusia melalui knowledge sharing di SMA Nurul Jadid dilakukan melalui; utilize materials, talk space, knowledge sharing culture, benchmarking best practices.
\end{abstract}

Kata Kunci: Knowledge sharing, Sumber Daya Manusia, Kualitas 


\section{INTRODUCTION}

In the era of the industrial revolution 4.0 (Muali, Wahid, Rahman, Najiburrahman, \& Fauzi, 2019), the trend of education is undergoing a significant transformation and a shift in orientation that places human development as a whole through education and training of various types, levels, characteristics, and forms (Chiedozie et al., 2018). The national development priority is placed in the economic sector, along with improving the quality of human resources (HR) (Widiansyah, 2018; Nuraeni, 2019), especially in the face of the era of globalization, free trade in the ASEAN region 2003 and the AsiaPacific region 2020.

The era of globalization promises a future full of challenges and competition (Kilis \& Uzun, 2020). The era of the universe, which is not limited by time and place, makes human resources who always want to improve their quality so that they are not left behind by others (Çalişkan, 2010). At this time, Indonesian people are entering the era of globalization and modernization which is full of challenges (Alwi, Wiyono, Bafadhal, \& Imron, 2019), which demands that Indonesian people become higher quality human beings with broad insights and all the skills they have (Krismiyati, 2017).

Human resources are the most important assets in an organization (Husnurofik, Mahmudah, \& Husaini, 2019), both for-profit and non-profit organizations. It is a source that drives, guides, maintains, and develops organizations in the various demands of society and the times (Susiawan \& Muhid, 2015)

Human resources in this case are a very important factor in any organization, both in form and in purpose (Yuliyati, 2020). The importance of human resources in an organization demands that every organization get qualified and productive employees to run the organization (Kalangi, 2015).

Many researchers say that human resources are very important for organizations. Research conducted by Aisyah et al., (2017) said that the quality of human resources has a positive and significant effect on employee performance, professionalism and employee commitment. This is also confirmed by Khadafi (2018), stating that job design and employee empowerment have a positive effect on improving employee performance. Dedik (2019) stated that the competency-based human resource management model can improve the performance of lecturers and employees to be more productive.

Human resources are seen as a very decisive process in organizational development (Öztürk, 2016), considering that the development of service quality will be realized if it is supported by qualified human resources (Dahlan, Hasim, \& Hamdan, 2017). Human resources need to be managed properly, so that they can play a role in accordance with their function, especially in educational institutions (Dakir, 2014; Owenvbiugie \& Ekhaise, 2019). For this reason, good and efficient human resource management (HR) is needed, 
especially for quality-oriented educational institutions (Cobanoglu, Sertel, \& Sarkaya, 2018).

Human Resource Management in educational institutions, especially at SMA Nurul Jadid, Paiton, Probolinggo is needed to increase the effectiveness of human resources in the organization. The goal is to streamline organizational performance. Resource development is directed at helping educators and education staff to have competencies and skills that lead to work professionalism (Krisdiyanto \& Nurhajati, 2017)

To improve the quality of education in the institution, human resources at SMA Nurul Jadid are well managed, so that existing resources can contribute well and be beneficial to the development of the institution. Moreover, the targets that have been determined together can be achieved well, so as to be able to provide satisfaction for consumers (Amir, 2019)

One of the strategies it does is knowledge sharing, which is the exchange of information and knowledge between two individuals that occurs at school. Knowledge sharing is a process in which individuals collectively and interactively improve a thought, idea, or suggestion according to instructions from individual experience (Imania, 2019). The main focus of knowledge sharing at SMA Nurul Jadid is that each individual is able to explain, understand and communicate information and knowledge to other people, groups, and especially to organizations.

Many researchers state that knowledge sharing has a big enough role for HR development, as conveyed by Alony et al., (2007) that knowledge sharing can improve organizational performance, increase competitive advantage, learning, innovation and organizational survival. Triana et al (2016), states that organizational communication has a significant influence on knowledge sharing and is able to improve employee performance. Anggraeni \& Aulawi (2018) suggest that knowledge sharing can improve organizational capabilities.

Given the importance of knowledge sharing, researchers are interested in studying strategies to improve the quality of human resources through knowledge sharing at SMA Nurul Jadid, Paiton, Probolinggo.

\section{RESEARCH METHODS}

This research uses a qualitative approach to the type of case study. The data collection technique was carried out through observation, interviews and documentation in order to obtain information about strategies for improving the quality of human resources through knowledge sharing at SMA Nurul Jadid, Paiton, Probolinggo. The data analysis was carried out in a circular manner, starting from data collection, data reduction and drawing conclusions as research findings. 


\section{RESULTS AND DISCUSSION}

The results showed that the strategy to improve the quality of human resources through knowledge sharing at SMA Nurul Jadid was carried out through the following:

\section{Utilize Materials}

Utilize Materials is understood as the media used by educators and education staff in carrying out knowledge sharing activities at SMA Nuru Jadid. The media are used to carry out knowledge sharing activities that include the use of several applications in several social media, such as Whats App, Telegram, Instagram, Zello, and so forth.

The use of information and communication technology in the form of social media is used as a medium for communicating, interacting, and socializing between individuals and individuals, or between individuals and all members of the organization at Nurul Jadid High School, without being limited by space, time and place.

According to Wicaksono (2020), various applications on social media, such as Whatsapp, telegram and Instagram are tools for communication, places for discussions, meetings, and many other benefits, both for young and senior teachers.

The purpose of sharing in the media makes it easier for educators and education personnel to communicate with each other, together to exchange information, ideas, suggestions, and experiences which in turn create the formation of new knowledge.

In addition to utilizing online technological devices, knowledge-sharing activities at Nurul Jadid High School are also carried out in person or face-toface. Through this face-to-face activity, educators and education staff can directly get information, exchange information, and so forth.

The form of direct knowledge sharing activities can be seen from the existence of Focus Group Discussion activities conducted by several teachers to exchange ideas and information. Munir (2020) states; "We often hold FGDs with teachers, both among teachers who live in SMA Nurul Jadid, and FGDs with teachers from outside SMA Nurul Jadid. Through this activity, we got a lot of information, knowledge, and new experiences related to many things.

Departing from the informant's statement, it can be seen that the knowledge sharing conducted by SMA Nurul Jadid has different variants, namely online and face-to-face. These media have their respective advantages and disadvantages, so that their use must be adapted to the situation, conditions, needs, and desired targets. 


\section{Talk Space}

The talk space provided by the school is a space or media for sharing and discussing various things carried out by leaders, teachers, and employees at SMA Nurul Jadid. According to Wicaksono (2020), sharing information and experiences that are usually done at Nurul Jadid High School is located in meeting rooms, computer labs, and in the school hall. The room is used as a place to discuss some of the problems that exist in schools, such as teacher performance, student problems, program development, upgrading, and so on. To improve the quality of human resources at Nurul Jadid High School, the sharing held by the school is carried out in a planned and systematic manner, usually once a month. If there is something very urgent, it can be done every week by involving related parties.

In addition, improving the quality of human resources is also carried out through monthly activities, such as workshops, training and seminars. The results of researchers' observations in the field showed that the workshop activities were held in a computer laboratory, with the theme of the activity "Evaluation and Optimization of E-reports" which was attended by all Nurul Jadid high school educators. This activity aims to increase teachers' knowledge about the SKS system and e-report card assessment.

Likewise, education and training activities are carried out to improve the competence of leaders, teachers, and employees. Activities that involve external parties in sharing information and experiences through knowledge sharing are often followed by the Nurul Jadid high school community, such as education and training activities in Malang, Surabaya, and other cities.

According to Munir (2020), they often participate in education and training activities as part of improving the quality of human resources in several cities and districts. This is following the needs of each unit or teacher. Through this activity, they gained a lot of new knowledge and experience provided by outsiders to be followed up at this institution. This statement was strengthened by Hanifiah (2020) who stated that knowledge and experience sharing activities were very beneficial, especially in supporting performance. This shows that SMA Nurul Jadid provides space and time for educators and education staff to upgrade knowledge and experience through knowledge sharing, where both activities are carried out inside and outside the school. This is because these institutions understand that sharing information and experiences is not only for improving the quality of its human resources, but also encourages the spread of individual learning throughout the organization, form which it has a positive effect on innovative work behavior.

\section{Knowledge Sharing Culture}

The culture of sharing is a culture of sharing knowledge and information at SMA Nurul Jadid, which encourages the improvement of the quality of teaching and education personnel and allows for the exchange of knowledge, 
insights, and experiences, thus leading to professional performance. Subject Teacher Deliberation (MGMP), a teacher working group (KKG) is a model used to improve the learning competence of teachers at SMA Nurul Jadid. The gathering of the teachers in order to carry out activities refers to the guidelines from the Ministry of Education and Culture of the Republic of Indonesia.

Subject Teacher Deliberation (MGMP) which is carried out routinely every one month is a form of teacher knowledge sharing involving external parties. Teachers gather in one agreed-on place, and that's where they equalize perceptions, discuss concepts, agree on issues to be discussed, and prepare steps to be taken by MGMP or KKG members in their implementation.

Wicaksono (2020) said that teachers as learning agents are obliged to design and develop a learning process that is interactive, inspirational, and fun, motivates students according to their talents and interests. This requires experience and knowledge obtained from other people through knowledgesharing activities. For example, groups make KKM (minimum completeness criteria) to determine the level of achievement of basic competencies that must be achieved by students in each subject. If a student has not reached the KKM, it is said that he is not finished. All educators who have the same or similar subjects will collaborate to design learning, determine learning strategies and media to be used, designing learning evaluations, making teaching materials, and so on.

MGMP activities are carried out on the principles of teachers, by teachers, and for teachers, so that with this principle, teachers can develop their knowledge and skills. In essence, the aim of MGMP activities is to improve the quality of learning which leads to optimal learning outcomes.

MGMP activities not only improve the quality of human resources at SMA Nurul Jadid, but also they benefit all educators and education personnel, such as increasing teacher competence and developing teacher abilities and skills to improve the quality of learning and new knowledge.

\section{Benchmarking Best Practices}

Benchmarking is an activity in which SMA Nurul Jadid conducts continuous self-evaluation by comparing its institutions with other institutions so that SMA Nurul Jadid can adopt and apply better overall practices from its partner institutions.

In the aspect of knowledge sharing, SMA Nurul Jadid tries to get information from external parties related to several things through field visit study activities. In practice, the teacher invites students to go into the field, looking at various advanced educational institutions, universities, or industrial companies. This is done to provide new understanding and experiences of the outside world so that they are motivated to become better at learning to look to the future. 
According to Wicaksono (2020), study tours or field studies are carried out by sending several teachers to study at other educational institutions, such as school institutions in Jombang, favorite state universities, several industrial companies, which are aimed at gaining new experiences, looking for learning methods, strengthening networks, and so on.

Apart from traveling, according to Faruk (2020), this activity is intended as a means of actual education and learning in the field. Participants will get a lot of information about many things, practical learning in the field, strengthen the material, enrich the experience and be able to generate enthusiasm for learning, so that the quality of their human resources can be improved. Besides, this activity can also provide opportunities for teachers and students to visualize, experience and discuss information, opportunities to exchange ideas.

Study tours are also good in shaping the personality of the civitas at Nurul Jadid High School. This is because educational tours provide a learning process far from the comfort of the classroom. So, participants can foster independence, leadership, and communication skills. By holding a study tour, teachers and students will meet new cultures, new people, and even new languages, so that they gain experience and can build a bolder and more confident personality. Their travel experiences make them independent individuals and help build future values and priorities at the institution. All of this will not be obtained from classroom learning, but directly in the field, in the best place.

Theoretically, knowledge sharing activities carried out by educators and education personnel at Nurul Jadid High School are not only to improve the quality of human resources, but also strengthen ukhuwah basyariyah between leaders, teachers, and employees at Nurul Jadid High School. Hence, interaction and harmonious communication can be obtained. In addition to ukhuwah basyariyah, this activity also strengthens institutional networks with external parties, thus providing a lot of input, new insights, and knowledge about many things. This will have implications for human resource management carried out by educational institutions in developing, motivating and evaluating all the human resources needed to achieve predetermined goals (Zamroni, 2017).

Human resource management in this case is understood as an activity that has the function of planning, organizing, implementing, and controlling sustainable resources (Harmen, Agustini, Aprinawati, \& Amanah, 2019). Therefore, the functions of human resource management at SMA Nurul Jadid are carried out in a planned, systematic, and directed manner so that the determined targets can be achieved effectively and efficiently (Almasri, 2016).

To improve the quality of human resources, knowledge sharing as an important and inseparable part of knowledge management needs to be developed (Andika, 2015). Knowledge sharing is an activity where individuals exchange information (Imania, 2019). Knowledge sharing that occurs at SMA Nurul Jadid does not only exchange information about learning with fellow 
educators, but they also seek or exchange information and knowledge with outsiders or other institutions to gain new knowledge and experiences about what is needed (Sonata, 2017).

Knowledge sharing is an interaction between individuals and individuals and groups with groups that aim to increase, channel and develop knowledge of individuals (Weda, 2018). Through knowledge sharing, educators and education staff can boost their resource capabilities, be able to create creative ideas, gather knowledge and enable institutions to increase their innovation.

Furthermore, knowledge management is understood as a way to identify, select, organize, and disseminate important information and expertise within an organization, as an effort to develop productivity and work performance, to increase the competitiveness of the organization. Besides, knowledge management can be used as a way to develop the potential of human resources in the organization (Nainggolan, 2015)

Knowledge management has three components, namely people, place, and content (Pratama, 2019). Beside of the three components, the role of information technology is to remove obstacles regarding places for discussion, sharing, where this activity aims to manage knowledge as an asset. Efforts are needed to distribute the right knowledge to the right people and in a fast time, so that they can interact with each other, share knowledge and apply it in their daily work for the sake of improving organizational performance.

\section{CONCLUSION}

Knowledge sharing carried out by the SMA Nurul Jadid community is an initiative of the leader to make innovations in improving the quality of resources in the institution, so that they have knowledge, experience, competence, and skills, and become professional in their performance. This effort is not easy, but it requires mutual interaction between all existing units, be it leaders, teachers, and employees so that the desired target can be achieved.

The research results above only present the strategies implemented by SMA Nurul Jadid in improving the quality of human resources through knowledge sharing. The results and the resulting impacts are not discussed in this assessment. Therefore, the limitations of this study provide an opportunity for further researchers to study various matters related to improving the quality of human resources in various perspectives, and thus it becomes a complement to scientific treasures on human resource management. 


\section{REFERENCES}

Aisyah, M. F., Utami, W., Sunardi, S., \& Sudarsih, S. (2017). Kualitas Sumber Daya Manusia, Profesionalisme Kerja dan Komitmen sebagai Faktor Pendukung Peningkatan Kinerja Karyawan PDAM Kabupaten Jember. E-Journal Ekonomi Bisnis dan Akuntansi, 4(1), 131-135. https://doi.org/10.19184/ejeba.v4i1.4753

Almasri, M. N. (2016). Manajemen Sumber Daya Manusia: Implementasi dalam Pendidikan Islam. Kutubkhanah: Jurnal Penelitian Sosial Keagamaan, 19(2), 133-151. https://doi.org/10.1002/eji.201370106

Alony, I., Whymark, G., \& Jones, M. (2007). Sharing Tacit Knowledge: A Case Study in The Australian Film Industry. Informing Science, 10, 41-59. https://doi.org/10.28945/3119

Alwi, M., Wiyono, B. W., Bafadhal, I., \& Imron, A. (2019). Diskripsi Hubungan Kepribadian, Emosi dan Perilaku "Orientasi Service" Guru di Era Industri 4.0. Al-Tanzim: Jurnal Manajemen Pendidikan Islam, 3(1), 227-250. https://doi.org/10.33650/al-tanzim.v3i1.519

Amir. (2019). Membangun Budaya Mutu pada Lembaga Pendidikan Islam Menuju Madrasah Unggul. Al-Tanzim: Jurnal Manajemen Pendidikan Islam, 3(2), 1-12. https://doi.org/10.33650/al-tanzim.v3i2.676

Andika, A. (2015). Meningkatkan Knowledge Sharing di Organisasi: Studi Literatur terhadap Faktor-Faktor yang Mempengaruhi Knowledge Sharing. Jurnal Penelitian dan Aplikasi Sistem dan Teknik Industri (PASTI), 9(3), 230-237.

Anggraeni, D. R., \& Aulawi, H. (2018). Pengaruh Knowledge Sharing pada Organisasi Kemahasiswaan dalam Meningkatkan Kemampuan Menyerap Pengetahuan Mahasiswa. Jurnal Kalibrasi, 16(1), 1-7.

Çalişkan, E. N. (2010). The Impact of Strategic Human Resource Management on Organizational Performance. Journal of Naval Science and Engineering, 6(2), 100-116. https:// doi.org/10.4172/2168-9601.1000213

Chiedozie, O. L., Victor, A. A., \& Sunday, F. T. (2018). Relationship between Staff Human Resource Management and Academic Performance of Accounting Students in Secondary Schools in Akoko South-West, Ondo State. Online Submission, 4(8), 31-41.

Cobanoglu, F., Sertel, G., \& Sarkaya, S. S. (2018). Human Resource Management Practices in Turkish Education System (Denizli Case). European Journal of Educational Research, 7(4), 833-847. https://doi.org/10.12973/eujer.7.4.833

Dahlan, Hasim, D., \& Hamdan. (2017). Pengaruh Manajemen Sumber Daya Manusia dan Budaya Organisasi terhadap Kualitas Pelayanan pada Kantor Kecamatan Tamalate Kota Makassar. Jurnal Administrare, 4(2), 6975.

Dakir. (2014). Manajemen Layanan Pendidikan Siswa Berkebutuhan Khsusus Prespektif Religious, Filosofis, Yuridis dan Historis. Yogyakarta: K-Media. 
Istiantara, D. T. (2019). Pengembangan Manajemen Sumber Daya Manusia Berbasis Kompetensi guna Meningkatkan Kinerja Pegawai dan Dosen Polikteknik Perkeretaapian Indonesia. Jurnal Perkeretaapian Indonesia (Indonesian Railway Journal), 3(2), 93-101.

Harmen, H., Agustini, F., Aprinawati, A., \& Amanah, D. (2019). Analisis Fungsi-Fungsi Manajemen Sumber Daya Manusia pada Beberapa Perusahaan Bumn di Kota Medan. Niagawan, 8(3), 140-147. https://doi.org/10.24114/niaga.v8i3.15572

Husnurofik, Z., Nurmahmudah, F., \& Usman, H. (2019). A Systematic Review on Sustainable Human Resource Management: A Framework for Managing Training in The Indonesian Police Force. First International Conference on Progressive Civil Society (ICONPROCS 2019), 160-164.

Imania. (2019). Strategi Knowledge Sharing Upaya Meningkatkan Kualitas Sumber Daya Manusia di Madrasah Diniyah Annafi'iyah Pondok Pesantren Nurul Jadid. Al-Fikrah: Jurnal Manajemen Pendidikan, 7(1), 2332. https:// doi.org/10.31958/jaf.v7i1.1405

Kalangi, R. (2015). Pengembangan Sumber Daya Manusia dan Kinerja. Jurnal LPPM Bidang EkoSosBudKum, 2(1), 1-18.

Khadafi, M. (2018). Pengaruh Praktik Manajemen Sumber Daya Manusia terhadap Kinerja Karyawan. Jurnal Mebis (Manajemen dan Bisnis), 3(1), 7583. https://doi.org/10.33005/mebis.v3i1.25

Kilis, S., \& Uzun, A. M. (2020). E-Learning in Sports Education Institutions in Turkey. Malaysian Online Journal of Educational Sciences, 8(1), 14-26.

Krisdiyanto, B., \& Nurhajati. (2017). Pengaruh Pengembangan Sumber Daya Manusia dan Motivasi terhadap Kinerja Pegawai Dinas Pariwisata Kota Batu. Jurnal Ilmu Manajemen, 2(2), 85-97.

Krismiyati, K. (2017). Pengembangan Sumber Daya Manusia dalam Meningkatkan Kualitas Pendidikan di SD Negeri Inpres Angkasa Biak. Jurnal Office, 3(1), 43-50. https://doi.org/10.26858/jo.v3i1.3459

Muali, C., Wahid, A. H., Rahman, K., Najiburrahman, \& Fauzi, A. (2019). Management of Islamic Higher Education Based on Benchmarking and Information Technology in the Revolutionary Era 4.0. Proceedings of 1st Workshop on Environme, 1-5.

Nainggolan, E. R. (2015). Membangun Knowledge Management System untuk Membentuk Knowledge Sharing Menggunakan Metode KM-Roadmap. Jurnal Pilar Nusa Mandiri, 11(1), 60-69.

Nuraeni. (2019). Manajemen Sumber Daya Manusia Lembaga Pendidikan. Jurnal Idaarah, 3(1), 124-137.

Owenvbiugie, R. O., \& Ekhaise, R. E. (2019). Human Resource Management Motivational Strategies for Enhancing Business Educators' Job Performance in Tertiary Institutions in Edo and Delta States, Nigeria. Journal of Education and Learning (EduLearn), 14(1), 140-147. https://doi.org/10.11591/edulearn.v14i1.14072 
Öztürk, S. (2016). Human Resources Management in Educational Faculties of State Universities in Turkey. International Journal of Environmental and Science Education, 11(5), 931-948.

Pratama, Y. A. (2019). Penerapan Knowledge Management di SMK Diponegoro Depok. Al-Idarah: Jurnal Kependidikan Islam, 8(2), 293-306. https://doi.org/10.24042/alidarah.v8i2.3521

Sonata, F. (2017). Analisis Survei Faktor-Faktor Knowledge Sharing dengan Teknik Focus Group Discussion (FGD) di Stikom Medan. Jurnal Teknologi Informasi dan Komunikasi, 6(1), 29-40.

Susiawan, S., \& Muhid, A. (2015). Kepemimpinan Transformasional, Kepuasan Kerja dan Komitmen Organisasi. Persona:Jurnal Psikologi Indonesia, 4(3), 304-313. https://doi.org/10.30996/ persona.v4i03.725

Triana, A., Utami, H., \& Ruhana, I. (2016). Pengaruh Komunikasi Organisasi terhadap Knowledge Sharing dan Kinerja Karyawan (Studi pada Karyawan Hotel Gajah Mada Graha Malang). Jurnal Administrasi Bisnis, 35(2), 86-93.

Weda, S. (2018). Knowledge Sharing Practices in EFL Classroom at Higher Education in Indonesia. TESOL International Journal, 13(1), 1-8.

Widiansyah, A. (2018). Peranan Sumber Daya Pendidikan sebagai Faktor Penentu dalam Manajemen Sistem Pendidikan. Cakrawala, 18(2), 299-234.

Yuliyati, E. (2020). Pengembangan Sumber Daya Manusia Berbasis Total Quality Management di SMK Muhammadiyah Prambanan. Al-Tanzim: Jurnal Manajemen Pendidikan Islam, 4(1), 24-35. https://doi.org/10.33650/al-tanzim.v4i1.967

Zamroni. (2017). Manajemen Mutu Pendidikan: Ikhtiar dalam Meningkatkan Mutu Pendidikan Madrasah melalui Pendekatan Balanced Scorecard. Tulungagung: Akademia Pustaka. 